\title{
The Position of a King in Safavid Period
}

\author{
Mohen Roozbeh Koohshahee
}

\author{
University of Sistan and Balouchestan, Zahedan. Iran
}

Corresponding Author: mohsenroozbehkoohshahee@gmail.com

Keywords: Safavid, king, position, holy, religious, Allah

\begin{abstract}
This article studies the position of the kings in the period of Safvid of Iranian Islamic History. The king in this period was considered as a holy figure. Indeed the king was considered and deemed as a great person encouraging a lot of respects. He was considered as the surrogate of prophet. Therefore he had a lot of unlimited powers and authorities. He was the symbol of excellence and raised the respect of anybody in the society. Since the Safavid dynasty itself was a religious one, based on the teaching of the twelve imams, it was important that the king be a religious person too. He is an emblem of God's bounty among humanity, he is the inauguration and termination for generosity among all human beings.
\end{abstract}

\section{INTRODUCTION}

The Safavid line was one of the most important ruling families of Persia after the collapse of the Sasanian dynasty - succeeding them since they were defeated by the Muslim Arabs in the seventh century A.D., and "is often considered the beginning of modern Persian history"(Encyclopcedia Iranica). The Safavid kings ran one of the so-called gunpowder kingdoms,( Streusand, 2011:135) and they administrated one of the greatest Persian kingdoms after the Muslim subjugation of Persia and founded the Twelver school of Shi'a Islam(Newman, 2012: 2) as the authorized religion of their kingdom, marking one of the most significant landmarks in Muslim history. As this makes crystal clear it is a religion dynasty. Such a religious dynasty make it clear the position of the king should be a religious one.

The Safavid line had its provenance in the Safaviyya Sufi order, which was founded in the city of Ardabil in the Azerbaijan district. The Safavid line was of varied lineage including among other Kurdish and Azerbaijani, which encompassed intermarriages with Georgian, Circassian, and Pontic Greek notables. From their headquarters in Ardabil, the Safavids exerted control over sections of Greater Iran and repeated the Iranian uniqueness of the region, consequently becoming the first native line since the Sasanian Empire to begin a unified Iranian state.(wikipedia)

The Safavids' reign lasted from 1501 to 1722 when they were at their prime. This dynasty was restored briefly from 1729 to 1736 . During their height they controlled all of modern Iran, Azerbaijan, Bahrain and Armenia, most of Georgia, the North Caucasus, Iraq, Kuwait and Afghanistan, in addition to parts of Turkey, Syria, Pakistan, Turkmenistan and Uzbekistan(ibid).

Notwithstanding the expiration in 1736, the inheritance that the Safavid Dynasty helped and contributed to the revitalization of Persia as an economic throttlehold between East and West, the formation of a well-organized state and system of government based upon "checks and balances", their architectural improvements and their sponsorship for fine arts. The Safavids have also left their mark down to the present period by dissemination of Shi'a Islam in Iran, together with foremost sections of the Caucasus, Anatolia, Mesopotamia, and Central Asia.(ibid)

Now we will study the position of kings of the Safavid Dynasty in Iran. As the country of Iran was a Muslim country, and the fact that the Safavid Dynasty was likewise Shia and Muslim, the king was not that different apropos of religion. He was a respectful man. Though to be a king meant to evoke respect and reveration, the king who was a Muslim himself evoke more respect than a non-Muslim king. This, in fact, finds expression in the Safavid dynasty. Most especially the kings 
of Safavid Dynasty believed to be Seyyeds. Seyyeds belong to family descendants of the Islamic prophet Muhammad himself. Concerning the fact of Seyyed, we have to recognize that Seyyeds evoke respect from any Muslim. An ordinary Seyyed who does not belong to the ruling power was loved during Safavid period, and is stilled loved and admired throughout Iran. When an ordinary Seyyed is loved that much, the case of a King-Seyyed in by far very different because Seyyeds are believed to be holy.

Concerning the position of King in Safavid period, Shah(King) was a messianic rallying figure whose middle name was justice, protection, love towards people. The king was considered to possess Iran as his own property like a man who possessed a house. The king was the sole giver of lands and the sole receiver of lands.(sanson, 133). The safavid king had completely limitless rights and was completely independent in ruling the country.

In establishing their successional ideology, the Safavid shahs efficaciously integrated an enormously different assembly of political, cultural, and religious individualities. The Safavid display broad-mindedness toward Achaemenian and Sasanian periods. The Safavid's religious method was not defined severely by mainstream Islamic understandings of prophecy and eschatology. They were not exclusive in their support of diverse ethnic rudiments, and they would from time to time display religious broad-mindedness toward native and foreign non-Muslims. Collin Mitchel in his book The Practice of Politics in Safavid Iran writes:

In Safavid official rhetoric imperial and pre-Islamic Persian icons stood side -by side with the greatest figures of Islamic prophecy and Shi ite hagiography: King Darius and the Prophet Muhamad, King Jamshid and Imam `Al1, Emperor Anüshırvan and the sixth Imam Ja far Sadiq. This in itself is not entirely surprising, given that the medieval Islamic period was known for its amalgamation of Islamic orthodoxy with pre-Islamic Iranian concepts of justice, kingship, and social hierarchy.(3)

\section{THE SAFAVID SHAH AS "THE PERFECT MAN}

In this period the king was considered a perfect man who was a great man with positive characteristics. Indeed the perfect man who be perfect in many respects, in fighting, in exercise, is archery and many others. In fact, the king or the Shah was supposed to be the perfect man in the region otherwise he could not protect the people. The king was influenced by Quran and its teaching and he was to observe them himself first and second her recommended those teachings to his followers. In fact, Quran was their most highly respected book and the rules of the prophet and his son-in-law Ali were highly respected by a king who was supposed to follow prophet and Ali. In fact, Quran explicitly decrees that every Muslim should follow the prophet and the king in this period did in fact follow Quran and set the prophet as his own example. He acted according to this rules of the Prophet. Most prominently, since the dynasty was a Shia Muslim, they respect Ali(PBUH) as their examples too. The king appointed his subjects based on the rules of the Quran, for example when he appointed somebody to a higher position he refer to Quran: 126: 3: "You give power to whom you please"; 17: 70: "We have conferred on them special favours above a great part of Our creation"; and 74: 39: “, We gave him[Joseph] power".

\section{THE MIRACULOUS NATURE OF THE SAFAVID SHAH}

The divine sanction that is found in Quran "The angels write out the decree of universal dominion in the sublime name of his sultanic Excellency, the shadow of God." Gives a divine position to the king of Saffavid. The king as the caliph and this caliphal authorization of the world has been dignified with the titulature: "Humayün, his Excellency, shah of shahs, he who has the dignity of Alexander." .(quoted by Mitchel) This is shown in the letter of the king to ottoman ruler in which the Ottoman ruler is likened to Alexander which in actual fact, shows the similarity of the Safavid king himself to Alexander. 
The Safavids believed that the king in this case Ismail was as "the holy of holies, full of divinatory power, for he takes counsel from no one ...his every act is divine-inspired."(quoted by Mitchel, 24) The king in this epoch was actually the shadow of God under whose protection everybody was secure. In fact it was the duty of the king or rather his objective to see the world and its inhabitants sitting in the shadow of security and safety cast by the Safavid standard of victory. The king in the Safavid period was a peerless and skillful ruler who is mandated divinely as they referred to Quran 3: 25: "You give power to whom You wish," and 6: 128: "For the earth is God's to give as a heritage to whomever he pleases." The king was given power by Allah according to the Safavid period. This is true about every king of this dynasty. Because he has been chosen and given power by Allah, he should be a real servant to Allah and should follow his rules as mentioned in Quran. Failure to do that, he will have great consequences for him and his subjects.

\section{CONCLUSION}

The position of the kings in the period of Safavid of Iranian Islamic History was scrutinized. The king in this period was deemed and regarded as a holy figure. Without a doubt the king was thought and deemed to be as a great person encouraging a lot of respect. He was believed and supposed to be the surrogate of prophet. Therefore he had a lot of unlimited powers and authorities. He was the symbol of excellence and raised the respect of anybody in the society. Since the Safavid dynasty itself was a religious one, based on the teaching of the twelve imams, it was important that the king be a religious person too. He is an emblem of God's bounty among humankind, he is the beginning and end for kindness and open-handedness among all human beings.

\section{References}

[1] Streusand, Douglas E., Islamic Gunpowder Empires: Ottomans, Safavids, and Mughals(Boulder, Col : Westview Press, 2011) ("Streusand"), p. 135.

[2]Iranica, Encyclopaedia. "Encyclopædia Iranica." (1995).

[3]Mitchell, Colin P. The practice of politics in Safavid Iran: power, religion and rhetoric. IB Tauris, 2009. Print.

[4] Newman, Andrew J. Safavid Iran: Rebirth of a Persian Empire. IB Tauris, 2012. Print.

[5]Streusand, Douglas E., Islamic Gunpowder Empires: Ottomans, Safavids, and MughalsBoulder, Col : Westview Press, 2011

[6]Wikipedia,. 2015. 'Safavid Dynasty'. Accessed $\quad$ September $14 \quad 2015$. https://en.wikipedia.org/wiki/Safavid_dynasty 